\title{
Understanding the Boundary between Information Systems and Organizational Semiotics: POS as Case Study
}

\author{
Manuel Ibarra ${ }^{1}$, Emerson Nahuinlla $^{1}$, Wilfredo Soto ${ }^{1}$, Vladimiro Ibañez ${ }^{2}$, Angel Na- \\ varro $^{3}$, Waldo Ibarra ${ }^{4}$ \\ ${ }^{1}$ Micaela Bastidas National University of Apurimac, Peru \\ ${ }^{2}$ National University of Altiplano Puno, Peru \\ ${ }^{3}$ Jose Maria Arguedas National University of Apurimac, Peru \\ ${ }^{4}$ San Antonio Abad National University of Cusco, Peru \\ \{manuelibarra, nahuinlla101131, wilsotopal, viqibanezquispe, \\ angelnr22\}@gmail.com, ibarrazambrano@yahoo.es
}

\begin{abstract}
Information systems have played an important role in organizations, especially in the business field. Organizational semiotics is one of the social technical approaches that considers information through the signs, norms or activities performed within an organization. This paper proposes a conceptual design of the boundary between information systems and organizational semiotics. To perform this task, a Point of Sale (POS) information system for a restaurant was developed as a case study in Apurimac Peru. The system allows the waiter to customize the food and drink orders. To validate this proposal three type of techniques were performed: document review, observation and interview. Also participated in the proof of concept the following people: waiter, customer, owner, cashier and cook. The collected results highlight the three layers and the morphology in the restaurant information system linked to organizational semiotics.
\end{abstract}

Keywords: Organizational Semiotics, Information System, Point of Sale, Restaurant.

\section{Introduction}

In recent years, Point of Sale (POS) information systems for restaurants have undergone interesting changes to implement various communication and information technologies to improve efficiency and customer service, among other aspects [1]. Decades ago, the restaurants used cash registers and papers with pens for annotations, now restaurants use POS terminals with touch screens and mobile devices. These changes encompass both the software and hardware that top-performing restaurants are using today to improve: customer satisfaction, business operations and increase revenues.

The definition of POS is a retail store, a cashier at the store, or the location where the transaction occurred. More specifically, POS often refers to the hardware and software used for checkouts - the equivalent of an electronic cash registers many years ago. 
POS are used in supermarkets, restaurants, hotels, stadiums, and virtually any type of retail business.

With growth in the use of mobile technology, nowadays, in the restaurants waiters can improve the food ordering using "all in one" computers with touch screens and mobile devices like tablets or cell phones. The allure of mobility, which enables tableside ordering and payment processing, may be having the greatest impact on purchase decisions, at least in table service environments [2].

According to Sarkar [3], the food ordering system, until a few years ago, was a completely manual process where a waiter used to note down orders from the customers using pen and paper, then take the orders to the kitchen, bring the food to the customer and then make the bill. Although this system was simple it required extensive investment in purchase and storage of paper, large manpower and also was prone to human errors and greater time consumption. In order to overcome these limitations in the manual systems, some systems were developed later like Personal Digital Assistant (PDA) based systems and touchable tablets restaurant management systems to automate food ordering process.

The restaurants are organizations with business that are highly prospective, because everyone has to eat and the amount of opportunities and the chance to grow are in line with the growing market. Employees and customers use signs, objects, norms and language to communicate each other, this means that they are using semiotics approach and information systems.

This article draws the relation between Information Systems and Organizational Semiotics, analyzing the objects of the ticket for Point of Sale System Information.

Section II of this article presents and discusses the document review; section III explains the design and implementation of the proposed design; section IV explains the findings of the proposed design; finally, section $\mathrm{V}$ describes the conclusions and future work of this research.

\section{Document Review}

Semiotics. Semiotics is the study of signs. Sign refers to anything that stands to someone for something else in a given context [4]. Also, it is the study of the meaning of sign processes and meaningful communication. This includes the study of signs and sign processes (semiosis), analogy, metaphor, symbolism, signification, and communication. Within the organizational semiotics literature, three forms of activities are discussed, namely substantive, communication and control [5].

Organizational Semiotics. Organizational Semiotics tries to understand organizations based on the use of all kinds of elements like: signs, texts, documents, sign-based artefacts and communication, thereby using the results of for instance psychology, sociology, economics, and information systems science as basic disciplines. One of the aims of organizational semiotics is to show what you are doing when you are trying to understand, design or change organizations in terms of the use of for instance models and metaphors. This is done in order to prevent people being trapped in the unconscious 
use of a specific metaphor or model type, and to make design space which is visible [6].

The Organizational Onion and Norms. The Organizational Onion categorizes Norms into three types: technical, formal and informal [5] as shown in the Figure 1. Technical Norms represent formal norms that have been digitalized; Formal Norms are documented and bureaucratic rules or standards into the organization; and Informal Norms are unstructured and undocumented rules or standards [4].

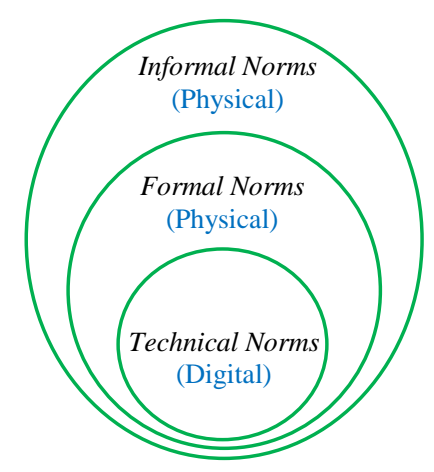

Fig. 1. The Organization Onion.

Semiotic Triangle. The study of signs must be united with the study of norms. From a triadic perspective, Peirce's version of semiotic triangle presents semantic relationship between: sign, object and interpretant [4]. Figure 2 shows that, as one interpretation, the interpretant must have knowledge or norm in order to associate the sign with the object.

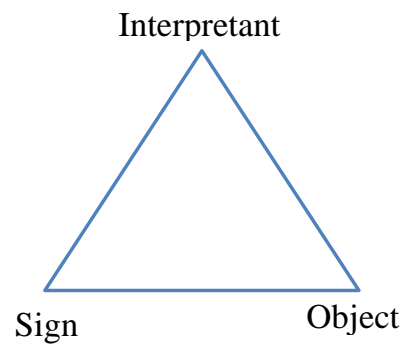

Fig. 2. The Semiotic Triangle

Semiotics and Information Systems. Stamper [7] has developed a semiotic framework (figure 3) which guides us in examining all the aspects of the signs and studying how signs are used for communication and coordination in an organizational context. 


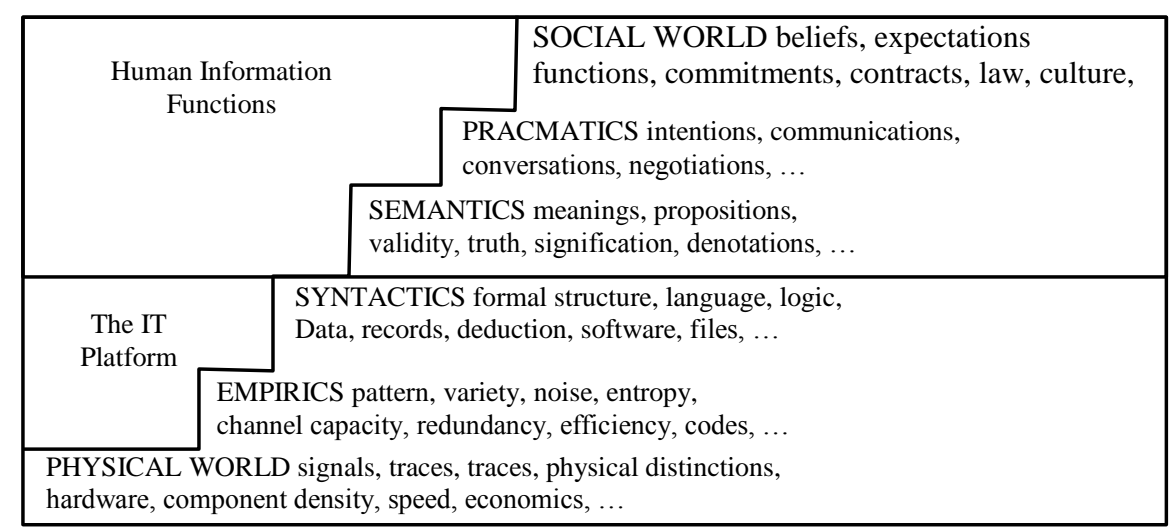

Fig. 3. The Semiotic Framework proposed by Stamper

Organizations have both a technical and a social dimension and their performance relies heavily on their ability to integrate both of these dimensions. From this semiotic perspective the IT platform serves the technical business operations whilst the human information functions capture the social dimension of business activities. From the semiotic perspective, an organization is essentially an information system. This is because in the organizations, information is created, stored, and processed to communicate, coordinate and to achieve the organizational objectives [8].

The organization is the whole system. Stamper [7] mention that: Within the organization, there are three categories of activities: Substantive (Organizational objectives), Communication (message passing) and Control (accomplishment of Substantive and Communication), as shown in figure 4 . The substantive activities are governed by the assignments and tasks that are derived from the organizational objectives within a given institutional structure. Results of the actions in this category are supposed to contribute directly to the attainment of the business goals of the organization. The actions will normally result in changes physically or socially [8]. 


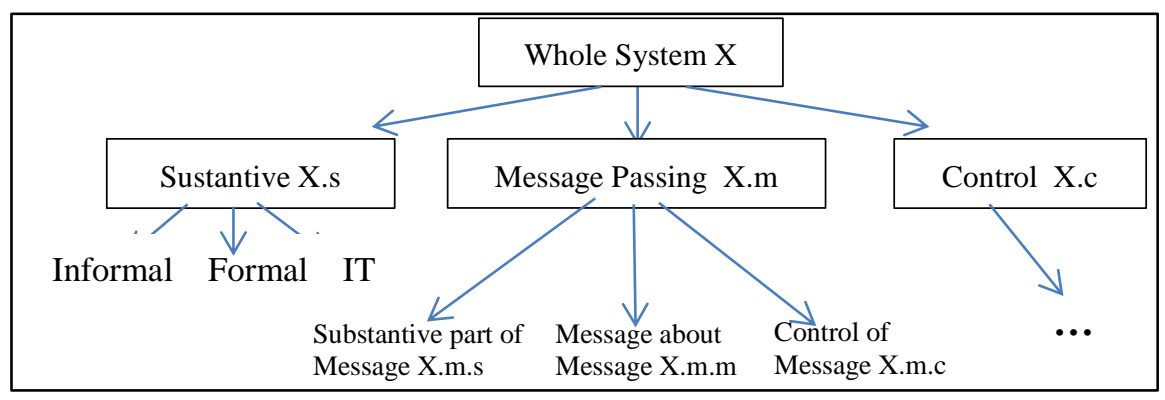

Fig. 4. System and categories of activities (morphology proposed by Stamper)

The substantive activities are carried out in three sub-systems; each depends on another and interacts with one another (figure 5). Informal context is represented as a subculture; Formal context is represented by defined norms or bureaucracy; and IT context automates part of the formal system. The scope of each sub-system is not always clear, and the boundary between these sub-systems can become fuzzy (therefore the dotted lines in the figure). Changing in one sub-system will definitely have impact on others. For example, re-engineering business processes will cause the need for re-design of the IT system, and vice versa [7].

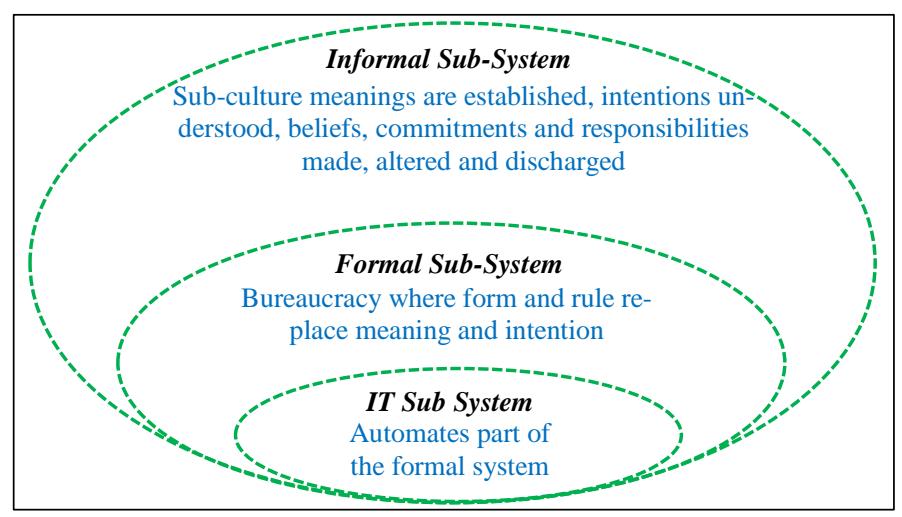

Fig. 5. Information System and Organization proposed by Stamper

\section{Conceptual Design}

Some research papers have attempted to explain the conceptual relationship between organizational semiotics and information systems in other context such as healthcare, education and business [9][10][11][12]. 
For this work we used the sign-based Semiotic Communication and the System Oriented Approach of Semiotic Organization which includes Sign System Oriented Approach. Sign System Oriented Approach studies media (spoken language, texts, instruments, computer interfaces) as sign systems, and see the use of these media by people as based on systems of narration and interpretation. User interaction with media (texts, computer interfaces, instruments) is observed, as well as communication between people at work [13].

\subsection{Logical Architecture for Restaurants Information System}

The process (formal and informal layer) starts when the customer calls the waiter to put the food order, then the waiter communicates the order to the cook in the kitchen area, cook prepares the food and waiter takes the food to the customer. Then the data is saved to the dataset hosted in a webserver. Finally, the owner can ask by queries to the database for decision making about total amount obtained in a day.

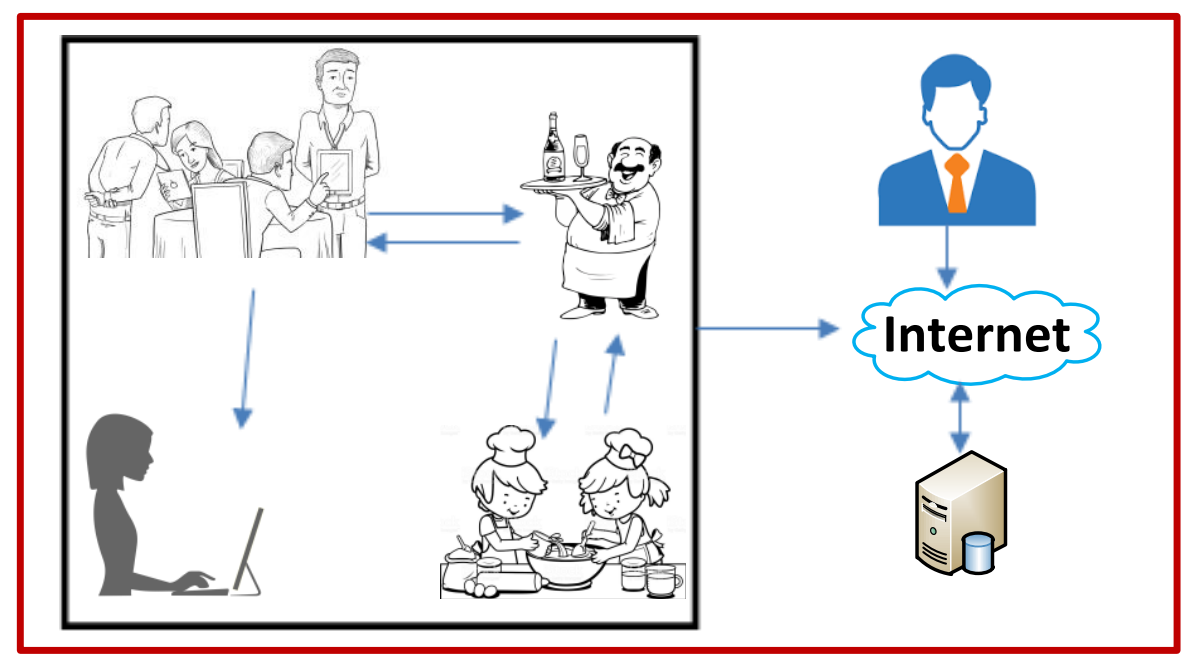

Fig. 6. Information System and Organization

\subsection{Methodology for this Qualitative Research}

This study adopts a qualitative research approach, for this purpose we perform three types of techniques presented as follows:

a) Theoretical and documentation review, this technique helped us to understand the main concepts of semiotics, information systems and POS, this documentation includes: papers, books, norms, internal regulations in restaurants and so forth. The results of this item are shown in theoretical section.

b) Observation, in this case, we observed the employee's and customer's daily activities into the tableside ordering and payment processing. 
c) Interviews, we conducted semi structured interviews to three waiters, five consumers and to the owner. The interviews were conducted at "Fastworkx" Company's leader office and "Il Gato pizzas and chicken" Restaurant in Abancay-Peru, on 27-30 September 2016. The results of the interviews are shown in Table 1.

Table 1. Interviews Results

\begin{tabular}{|c|c|c|}
\hline Type & Question & Answer \\
\hline \multirow{5}{*}{ Owner } & $\begin{array}{l}\text { Which are the principal rules or } \\
\text { norms for the restaurant? }\end{array}$ & $\begin{array}{l}\text { - Schedule attention is one written rule } \\
\text { - Accounting rules, but it is done by an ex- } \\
\text { ternal worker. }\end{array}$ \\
\hline & $\begin{array}{l}\text { What information do you need } \\
\text { for improve decision making? }\end{array}$ & $\begin{array}{l}\text { - Total amount collected in the day is im- } \\
\text { portant, } \\
\text { - The most requested meals also it is im- } \\
\text { portant. Who is my best waiter? for exam- } \\
\text { ple is very important. }\end{array}$ \\
\hline & $\begin{array}{l}\text { Are there some informal rules } \\
\text { for the business environment? }\end{array}$ & $\begin{array}{l}\text { - Discounts and Promotions in some days of } \\
\text { the week, for example on Tuesday because } \\
\text { we have less customers to attend. } \\
\text { - Sometimes home delivery, but often times } \\
\text { we don't have human resources to attend it. } \\
\text { - Customer always has the reason! }\end{array}$ \\
\hline & $\begin{array}{l}\text { How do you know the opinion } \\
\text { of the customers? }\end{array}$ & $\begin{array}{l}\text { - By the claims book, or sometimes by tele- } \\
\text { phone calling. }\end{array}$ \\
\hline & $\begin{array}{l}\text { How do you control de norms } \\
\text { accomplishment in your busi- } \\
\text { ness? }\end{array}$ & $\begin{array}{l}\text { - Some accounting information is given by } \\
\text { the POS system, but others not. }\end{array}$ \\
\hline \multirow{3}{*}{ Waiters } & $\begin{array}{l}\text { Does the POS implemented } \\
\text { with touch screens improve } \\
\text { your time attention to the cus- } \\
\text { tomer? }\end{array}$ & $\begin{array}{l}\text { - Of course, and we can add or delete food } \\
\text { or drink items, now we can join tables in } \\
\text { the system. }\end{array}$ \\
\hline & $\begin{array}{l}\text { How is the communication } \\
\text { with food area? }\end{array}$ & $\begin{array}{l}\text { - Something important is that with the im- } \\
\text { plementation of the system, we don't need } \\
\text { to go many times to the food area (as we } \\
\text { did before). }\end{array}$ \\
\hline & $\begin{array}{l}\text { How is the communication } \\
\text { with cashier? }\end{array}$ & $\begin{array}{l}\text { - The cashier can see all orders and the } \\
\text { amounts in the computer screen. }\end{array}$ \\
\hline \multirow[b]{2}{*}{ Customer } & $\begin{array}{l}\text { How is the communication } \\
\text { with the customer? }\end{array}$ & $\begin{array}{l}\text { - The communication is calling the waiter } \\
\text { for food order and payment }\end{array}$ \\
\hline & $\begin{array}{l}\text { The time attention (before } \\
\text { touch screen was implemented) } \\
\text { is less than POS system was } \\
\text { implemented? }\end{array}$ & - I think so \\
\hline
\end{tabular}




\section{$4 \quad$ Findings}

This section presents the results of the methodology applied to the analysis of the relation between information system and the semiotics. The results of the Theoretical and documentation review are shown in theoretical section.

\subsection{Describing Morphology for a Restaurant Information System}

The results of observation are shown in Fig. 6. Finally, the results of the interviews are summarized in the Table 2 . The interview results were taken and aligned with the concepts of the theoretical section, the proposal for the Morphology of Restaurant Information System was designed, as shown in the Table 3, and also Restaurant Information System Layers are shown in the Table 1.

Table 2. Description of layers of Restaurant POS

\begin{tabular}{lll}
\hline Layer & Description & Example for Restaurant \\
\hline Informal & Cultural pat- & - Promotions \\
& terns norms & - Discounts \\
& & - Home delivery \\
\hline Formal & Play dominant & - Attention to the Schedule \\
& roles & - Statistical information about consumption and earn- \\
& & ings for decision making. \\
\hline Technical & IT System & - Touch screen computer and mobile devices \\
& & - Ticket Printer \\
& & - Router \\
& & - POS software \\
& & - Network Connectivity \\
\hline
\end{tabular}

\subsection{Describing Morphology for Restaurant Information System}

Morphology describes the Activity and Description for Restaurant POS. Table3 shows the Morphology for POS service.

Table 3. Morphology of Restaurant POS

\begin{tabular}{|c|c|c|}
\hline Activity & Description & Example for Restaurant \\
\hline Substantive & $\begin{array}{l}\text { The objective } \\
\text { norms }\end{array}$ & $\begin{array}{l}\text { - Quality of attention to customers } \\
\text { - Total amount earned during the day } \\
\text { - Time for food ordering process }\end{array}$ \\
\hline Communication & $\begin{array}{l}\text { The interaction re- } \\
\text { lated norms. }\end{array}$ & $\begin{array}{l}\text { - Message from customer to waiter (food order) } \\
\text { - Message from waiter to Food preparation area (pre- } \\
\text { pare food order) } \\
\text { - Message from customer to cashier area (Payment for } \\
\text { consumption) }\end{array}$ \\
\hline Control & $\begin{array}{l}\text { The execution re- } \\
\text { lated norms }\end{array}$ & $\begin{array}{l}\text { - Reviewing book of claims (customer satisfaction) } \\
\text { - Reviewing revenues (earnings) }\end{array}$ \\
\hline
\end{tabular}




\section{$5 \quad$ Conclusions and Future Work}

This paper explores the relation between organizational semiotics and information system especially in the restaurant business field. For this purpose, a Point of Sale information system was developed to compare the theoretical concepts and the practical approach. The study was conducted qualitatively by using techniques of documentation review, observation and interview. The information collected in documentation review allowed us to understand the main concepts or organizational semiotics and technical, formal and informal norms. The results obtained by the observation conducted us to know; the activities performed by the stakeholders (customer, waiter/waitress, cook, owner, and cashier); the communication between stakeholders; the business process management into the organization and the logical architecture of the Point of Sale system for restaurants. The results obtained by interview summarized the morphology for Restaurants Information System aligned with the Organizational Semiotics concepts. In future work, it is necessary to validate this proposal with other restaurants in different contexts.

\section{References}

1. Ruiz-Molina, M.E., Gil-Saura, I., and Berenguer-Contri, G.: Information and communication technology as a differentiation tool in restaurants, J. Foodserv. Bus. Res., vol. 17, no. 5, pp. 410-428 (2014).

2. Bhargave, A., Jadhav, N., Joshi, A., Oke P. and Lahane, S.R.: Digital Ordering System for Restaurant Using Android, Int. J. Sci. Res. Publ., vol. 3, no. 4, pp. 1-7 (2013).

3. Sarkar, S., Shinde, R., Thakare, P., Dhomne, N., and Bhakare, K.: Integration of Touch Technology in Restaurants using Android, Int. J. Comput. Sci. Mob. Comput., vol. 3, no. 2, pp. 721-728 (2014).

4. Stamper, R., Liu, K., Hafkamp, M. and Ades, Y.: Understanding the roles of signs and norms in organizations - a semiotic approach to information systems design, Behav. Inf. Technol., vol. 19, no. 1, pp. 15-27, Jan. (2000).

5. Liu K.: Semiotics in information systems engineering, no. September. Cambridge University Press (2000).

6. Gazendam, K., Jorna, H. W. M., Liu R. J.: An organizational semiotic view on interculturality and globalization, Round Table Workshop , in Proceedings of the IASS 2004 Conference, pp. 1-11 (2004).

7. Stamper, R. K. : Signs, Information, Norms and Systems, in Signs of Work: Semiotics and Information Processing in Organisations, pp. 349-399 (1996)

8. Liu, K. and Sun, L. : Preface : Co-Design of Business and IT Systems (2002).

9. Liu, S., Liu, K. and Li, W.: A multi-agent system for pervasive healthcare, in 14th International Conference on Informatics and Semiotics in Organisation (ICISO), pp. 97-105 (2013).

10. Liu, S., Li W., and Liu, K.: Assessing pragmatic interoperability of information systems from a semiotic perspective, in International Conference on Informatics and Semiotics in Organisations, pp. 32-41 (2014).

11. Tan, C. and Liu., K.: An organisational semiotics inspired information architecture: Pervasive healthcare as a case study, ICISO 2013 - Proc. 14th Int. Conf. Informatics Semiot. Organ. IFIP WG8.1 Work. Conf., pp. 35-44 (2013). 
12. De Souza Santos, M. C., Bertãozini, B. D. S. M. and De Almeida Neris, V. P. : Studies in Organisational Semiotics: A Systematic Literature Review", In International Conference on Informatics and Semiotics in Organisations ICISO, pp. 13-24 (2016).

13. Ibarra, M.J., Serrano, C., and Muñoz, J. C.: SIERA : Improving Data Visualization for Learning Assessment in Educational Organisations, in International Conference on Informatics and Semiotics in Organisations ICISO, pp.191-196 (2016). 